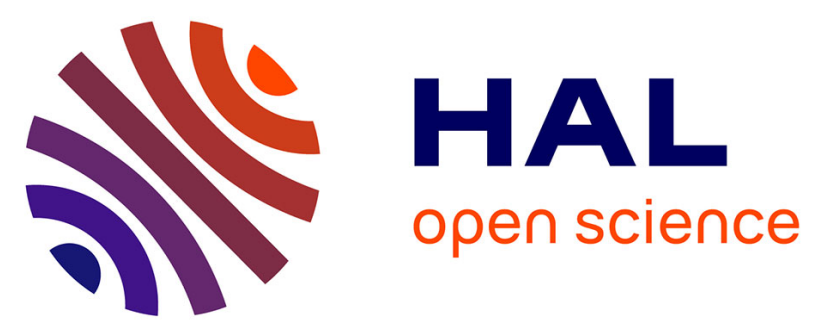

\title{
Heat treatment in the South African Middle Stone Age: temperature induced transformations of silcrete and their technological implications
}

Patrick Schmidt, Guillaume Porraz, Aneta Slodczyk, Ludovic Bellot-Gurlet, William Archer, Christopher E. Miller

\section{To cite this version:}

Patrick Schmidt, Guillaume Porraz, Aneta Slodczyk, Ludovic Bellot-Gurlet, William Archer, et al.. Heat treatment in the South African Middle Stone Age: temperature induced transformations of silcrete and their technological implications. Journal of Archaeological Science, 2013, 40 (9), pp.35193531. 10.1016/j.jas.2012.10.016 . hal-01544789

\author{
HAL Id: hal-01544789 \\ https://hal.science/hal-01544789
}

Submitted on 12 Jul 2018

HAL is a multi-disciplinary open access archive for the deposit and dissemination of scientific research documents, whether they are published or not. The documents may come from teaching and research institutions in France or abroad, or from public or private research centers.
L'archive ouverte pluridisciplinaire HAL, est destinée au dépôt et à la diffusion de documents scientifiques de niveau recherche, publiés ou non, émanant des établissements d'enseignement et de recherche français ou étrangers, des laboratoires publics ou privés. 


\title{
Heat treatment in the South African Middle Stone Age: temperature induced transformations of silcrete and their technological implications
}

\author{
Patrick Schmidt ${ }^{\mathrm{a}, *}$, Guillaume Porraz ${ }^{\mathrm{b}}$, Aneta Slodczyk ${ }^{\mathrm{c}}$, Ludovic Bellot-gurlet ${ }^{\mathrm{c}}$, \\ William Archer ${ }^{\mathrm{d}, \mathrm{e}}$, Christopher E. Miller ${ }^{\mathrm{f}}$ \\ a University of Tübingen Department of Prehistory and Quaternary Ecology Schloss Hohentübingen 72020 Tübingen, Germany \\ ${ }^{\mathrm{b}}$ CNRS, UMR 7041, ArScAn/AnTET, Maison de l'Archéologie et de l'Ethnologie, Université de Paris X, 21 allée de l'Université, F-92023 Nanterre, France \\ ${ }^{\mathrm{c}}$ Laboratoire de dynamique, interactions et réactivité (LADIR) UMR 7075, CNRS and UPMC (Université Pierre et Marie Curie, Paris 6), 4 Place Jussieu, \\ 75252 Paris Cedex 05, France \\ d Archaeology Department, University of Cape Town, Private Bag, Rondebosch 7701, South Africa \\ e Department of Human Evolution, Max Planck Institute for Evolutionary Anthropology, Deutscher Platz 6, D-04103 Leipzig, Germany \\ ${ }^{\mathrm{f}}$ Institute for Archaeological Science, University of Tübingen, Ruemelinstr. 23, 72070 Tuebingen, Germany
}

\section{A R T I C L E I N F O}

\section{Article history:}

Received 21 August 2012

Received in revised form

16 October 2012

Accepted 19 October 2012

\section{Keywords:}

Heat treatment

Silcrete

MSA

South Africa

Thermal properties

Raw material

\begin{abstract}
A B S T R A C T
It was recently found that silcrete raw material was heat-treated during the South African Middle Stone Age (MSA) for altering its flaking properties. This finding led to hypotheses about the implications for the MSA hunter-gatherers such as the cost of thermal treatment in terms of investment and firewood. To date, these hypotheses lack a solid basis, for data on the thermal transformations of South African silcrete and, hence, the necessary heating procedure and heating environment, is missing. In order to produce such data, we conducted an experimental study within the framework of the Diepkloof project. This work is based on the petrographic, mineralogical and structural analysis of South African silcrete from the West Coast and its thermal transformations. Our results shed light on the nature of these transformations, the ideal heating temperatures and the tolerated heating speed. The processes occurring in silcrete are comparable to flint, i.e. the loss of chemically bound 'water' and the formation of new $\mathrm{Si}-\mathrm{O}-\mathrm{Si}$ bonds, but their intensity is less pronounced. Effective heating temperatures are significantly higher than for flint and the heating speed tolerated by South African silcrete is relatively fast. These findings imply that silcrete heat treatment cannot be directly compared with flint heat treatment. Unlike flint, heating silcrete does not require the setup of a dedicated heating environment and may have been performed in the same time as other fire related activities. This would represent only a minor supplementary investment in time and firewood. These results have broad implications for the discussion about technological evolution and the acquisition of specialised knowledge in the MSA.
\end{abstract}

(c) 2012 Elsevier Ltd. All rights reserved.

\section{Introduction}

The South African Middle Stone Age (MSA) corresponds to a set of technological and behavioural innovations comparable to, but predating, those of the European Upper Palaeolithic by several tens of thousands of years. These innovations include the production of composite tools and complex hafting materials (Charrié-Duhaut et al., 2013; Wadley et al., 2009), the production of bone points (Backwell et al., 2008), and the use of symbolic expression

\footnotetext{
* Corresponding author. Tel: +497071 2977323.

E-mail address: patrick.schmidt@uni-tuebingen.de (P. Schmidt).
}

(Henshilwood et al., 2004, 2002; Texier et al., 2010; Texier et al., 2013). However, the exact moment of their appearance and the mechanisms behind these innovations remain subject to discussion (Klein, 1995; Jacobs and Roberts, 2009; McBrearty and Brooks, 2000; Tribolo et al., 2013; Porraz et al., 2013). The intentional transformation of raw material used for the production of stone tools seems to have been a part of this phenomenon.

It has recently been shown that the South African MSA yielded the earliest known traces of heat treatment of raw material for tool production (Brown et al., 2009; Mourre et al., 2010). Lithic heat treatment is the controlled transformation of a material's properties by the influence of heat. It can therefore be considered as one of the first procedures man used to intentionally alter a material, 
hence an evolutionary step requiring intimate knowledge and control of fire and complex cognitive abilities. It has even been proposed that heat treatment accounts for the presence of advanced tools in the African MSA and that it may have created an advantage for early modern humans during their dispersal into Eurasia (Brown et al., 2009).

In order to comprehend the implications of these early cases of heat treatment for behavioural evolution during the MSA, it appears necessary to understand the challenges faced by the authors of this process and the cost of its execution in terms of investment. We therefore propose to investigate the technological conditions required for the thermal transformation of the rocks used as raw materials in the South African MSA. This paper contains a contribution to an improved understanding of MSA lithic technology and is part of a broader study engaged at the site of Diepkloof Rock Shelter (Parkington et al., 2013).

\section{Background of the study}

\subsection{Archaeological background}

From the 1960s on, heat treatment of raw material has been identified from the Upper Palaeolithic, the Neolithic, the Mesolithic, North American Paleo-Indian groups and some recent and sub-recent ethnographic descriptions (Crabtree and Butler, 1964; Bordes, 1969; Tiffagom, 1998; Binder, 1984; Léa, 2005; Kenoyer et al., 1991; Hester, 1972; Inizan and Tixier, 2001; Eriksen, 2006). Throughout the archaeological record, this process seems to have been in close association with pressure flaking, either for the retouch of bifacial tools or the production of blades and bladelets.

A recent discovery at the South African MSA site of PP5/6 at Pinnacle Point (Brown et al., 2009) considerably pushes back the date of the appearance of lithic heat treatment. The authors concluded that the thermal transformation of silcrete was regularly practised 72,000 years ago and that it appeared as early as 164,000 years ago. During this study, the majority of the analysed PP5/6 artefacts made on silcrete were found to be heated and, since these artefacts were recovered from unburned archaeological contexts, the authors concluded that the heat treatment was intentional. Whether other rocks, like quartzite, were also heated is not specified by Brown et al. (2009). Another recent study (Mourre et al., 2010) also recognised heat treatment of silcrete from the Still Bay layers at the site of Blombos Cave. At this site, heat treatment was performed on blanks prior to their shaping, hence consistently entering into the chaîne opératoire as a supplementary step. As in later examples from the European Upper Palaeolithic and the Neolithic, heat treatment in the South African Still Bay also seems to be in association with pressure flaking (Mourre et al., 2010). However, it was also documented that flakes were heated prior to their (rather simple) retouch into denticulates (Mourre et al., 2010), hence questioning the association of heat treatment with a high technical investment for elaborate tool shapes.

The discovery of heat treatment in the South African MSA is an important step towards a better understanding of Pleistocene lithic technology in southern Africa and the related raw material provisioning strategies. The Howiesons Poort (HP) and, to a lesser extent, the Still Bay (SB) are technological phases accompanied by the increasing use of silcrete. These changes in raw material provisioning throughout the MSA reflect a modification of the territorial organisation of these populations (Ambrose and Lorenz, 1990). Brown and Marean (2010) proposed these changes to be related to the changing availability of firewood for heat treatment. This hypothesis rests upon the assumption that heat treatment is indispensable for silcrete knapping and that heat treatment requires supplementary firewood for the setup of a special heating environment. It would therefore be a supplementary investment for tool production requiring extra resources and, hence be economically advantageous only when firewood is abundant or when the access to high quality raw material is restricted (Brown and Marean, 2010).

At Diepkloof Rock Shelter, thermally transformed artefacts appear in the pre-SB layer 'Lynn' and last until the post-HP layers (Porraz et al., 2013). It appears clear that some silcrete artefacts were knapped after having been heated but whether the heating represents an intentional or an accidental step is still to be demonstrated since combustion residues are widespread throughout the whole sequence (Miller et al., 2013) and other rock types, like quartzite, have also been heated (Tribolo et al., 2013).

We believe that determining heat treatment on prehistoric artefacts needs to be based on archaeometric techniques (some of which appear to be more appropriate than others) and a broader technological understanding of the lithic chaîne opératoire. The implications of the finding of heat treatment at a given period, the challenges it dictates to the makers and the adopted solutions can only be understood through an intimate knowledge of the used materials and their thermal transformations. The search for the Pleistocene people's technological knowledge and its place within their society must therefore begin with the analysis of the heattreated materials.

\subsection{The thermal transformation of silica rocks and the silcrete issue}

In order to understand heat treatment of silica rocks, several authors proposed models explaining their temperature induced transformations. The implication of secondary elements like iron oxides were discussed (Purdy and Brooks, 1971; Schindler et al., 1982) along with internal fracturing (Flenniken and Garrison, 1975) and recrystallisation (Domanski and Webb, 1992). Many of these models were contradictory, incomplete or simply found to be incorrect (a more detailed description of past models is given in the introduction of Schmidt, 2011). More recently, Schmidt et al. (2012b) proposed a model of the temperature induced crystallographic and structural transformations in length-fast (LF) chalcedony and flint. LF-chalcedony consists of a fabric of nanometresized $\alpha$-quartz crystallites that are arranged in fibres (Rios et al., 2001). The quartz $c$-axis is normal to the fibre axis (Michel-Levy and Munier-Chalmas, 1892). Flint is predominantly made up of short intersecting chalcedony fibres. These rocks contain up to $0.7 \mathrm{wt} \%$ of chemically bound water as $\mathrm{SiOH}$ (silanole) and about the same amount of molecular water (Schmidt et al., 2011) that is retained in the structure of the rock (i.e. liquid inclusions between grain boundaries and crystal defects within the quartz crystallites (Flörke et al., 1982; Graetsch et al., 1985)). Chalcedony is also a porous rock allowing water circulation throughout its structure and the amount of water that can be absorbed by open pores typically builds up $\approx 0.25$ wt\% of the rock (Schmidt et al., 2011).

In order to identify and quantify the transformations undergone by LF-chalcedony during heat treatment, Schmidt et al. (2012b) used different techniques including infrared spectroscopy, solid state NMR, X-ray diffraction and scanning electron microscopy. Their results showed that the major transformation is the loss of silanole and the creation of new bridging $\mathrm{Si}-\mathrm{O}-\mathrm{Si}$ bonds according to the reaction:

$\mathrm{Si}-\mathrm{OH}+\mathrm{HO}-\mathrm{Si} \rightarrow \mathrm{Si}-\mathrm{O}-\mathrm{Si}+\mathrm{H}_{2} \mathrm{O}$

This reaction starts between $200{ }^{\circ} \mathrm{C}$ and $300{ }^{\circ} \mathrm{C}$ and causes the healing of defect sites within crystals and the closing of the rock's 
pores. This results in an increase in hardness of the rocks. The material's hardness is correlated with its fracture toughness (Le Bourhis, 2008) improving in this way the flaking properties of the rock (Schindler et al., 1982; Domanski et al., 1994). The maximal annealing temperature and ramp rate were found to be functions of the ability of the structure to evacuate newly created $\mathrm{H}_{2} \mathrm{O}$ and depend on the size of the heated specimen and the volume of its porosity. The heating temperature of medium to large samples must therefore remain relatively low and the heating speed slow for the created water to be evacuated before the resulting vapour pressure at higher temperatures induces internal fracturing and, hence, failure of the treatment. This need for water evacuation makes heat treatment of flint a time consuming and difficult task requiring the setup of a special heating environment that allows for creating and maintaining very precise conditions.

Thus, a large part of the thermal transformations of flint and other silica rocks consisting of pure or almost pure LF-chalcedony seem to be understood. However, heat treatment in the South African MSA was not performed on such rocks but on silcrete (Brown et al., 2009). Contrary to marine flint, silcrete is a terrestrial paedogenic silicification that forms by induration of an existing sediment by micro-cryptocrystalline silica cement (Summerfield, 1983; Wopfner, 1978). The rock is mostly composed of quartz that is present as grains surrounded by a matrix of micro- to cryptocrystalline quartz (Summerfield, 1983). Its structure is therefore different from flint leading to differences in its expected thermal behaviour. These differences need to be understood and a model of the heat induced transformations in silcrete must be proposed in order to investigate the role of silcrete heat treatment in the context of technological adaptations in the MSA.

We present here an approach based on near infrared (NIR) spectroscopy, Raman spectroscopy, X-ray diffraction (XRD) and thermogravimetric (TG) analyses aiming to identify the sample's mineralogical content and to measure their content of different 'water' species before and after experimental heat treatment. The role of non-quartz impurities is also discussed. This approach highlights the structural peculiarities and thermal behaviour of silcrete used for heat treatment in the MSA.

\section{Samples and experimental}

\subsection{Sampling and sample preparation}

All samples were collected during geological survey in the West Coast area, aiming to document the spatial distribution of silcrete outcrops and their variability. Fieldwork was conducted within the framework of the Diepkloof project and is described in detail in Porraz et al. (2013) (also containing macroscopic descriptions and photographs of the samples). 57 silcrete outcrops were sampled from (sub-) primary $(N=45)$ and secondary $(N=12)$ positions, representing the silcrete types found in the archaeological records of Diepkloof Rock Shelter and some other sites on the West Coast of the Western Cape region. For the present analysis, eleven samples were selected from this geological collection. These include specimens from the immediate surroundings of Diepkloof but also from its south (Malmesbury area) and north (Olifants river mouth). Samples SA-11-2 and -17A were collected in primary position, samples SA-11-56, -56b, -61F and -65B in secondary position and the remaining samples were collected in sub-primary position (Porraz et al., 2013). Exact sample provenances are summarised in Fig. 1. Silcrete varieties with different macroscopic characters were chosen ('coarse-grained' and 'fine-grained') representing the diversity of silcrete occurring in the West Coast (Roberts, 2003).

In order to assess the sample's mineralogical composition by means of infrared and Raman spectroscopy, all eleven samples

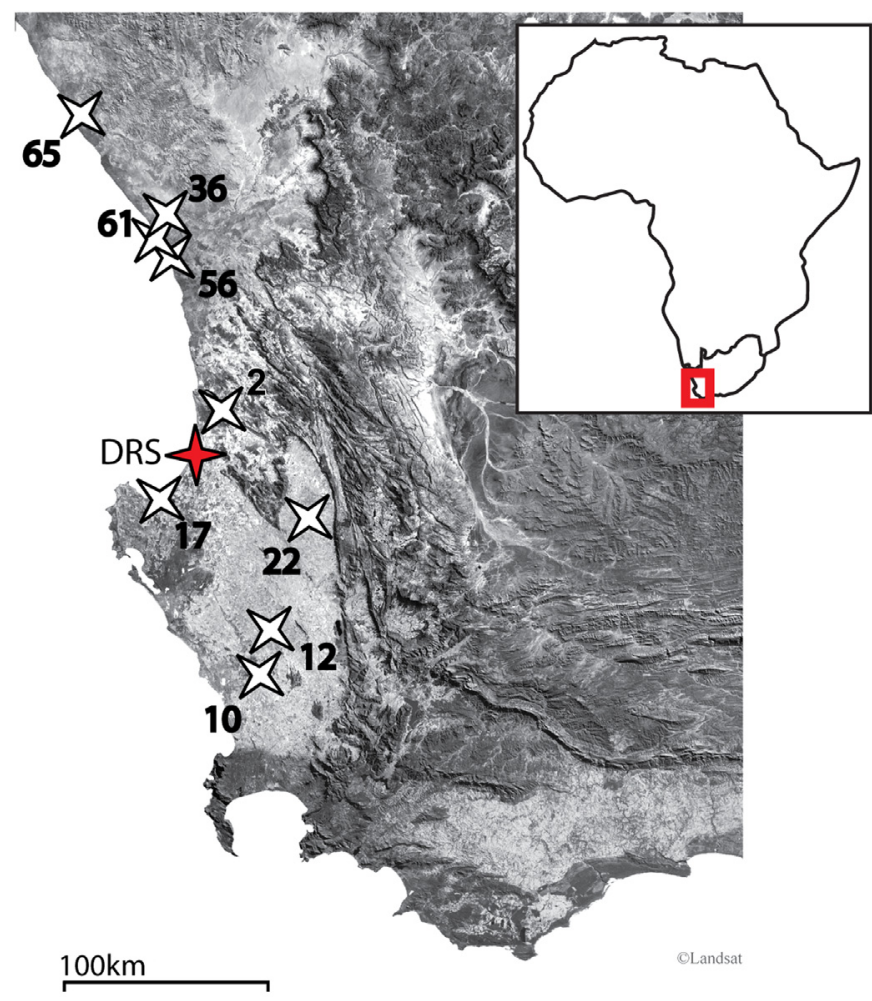

Fig. 1. Map showing the sample locations of the 11 silcrete samples. Numbers on the map correspond to the last cyphers of the sample numbers (i.e. 56 for SA-11-56 and SA-11-56b). DRS = Diepkloof Rock Shelter.

were cut into slabs of a thickness of approximately half a millimetre and diamond polished on both sides (exact sample thicknesses are summarised in Table 2). Petrographic thin sections (thickness $30 \mu \mathrm{m}$ ) for microscopic observations in polarised light were cut from all samples. Additionally, powders with a grain size between 4 and $25 \mu \mathrm{m}$ were prepared from 6 samples for X-ray powder diffraction analysis (Table 1). TG analysis was performed on two fragments weighing $\approx 50 \mathrm{mg}$ of samples SA-11-12A and -36 . For better comparability between TG and NIR data, both fragments for the TG measurements were broken off from the polished slabs used for the infrared analyses and therefore have the same thickness. In order to evaluate the maximum tolerated heating speed of the studied silcrete samples, flakes weighing from 18 to $205 \mathrm{~g}$ were removed from seven of the silcrete samples. Their sample numbers, masses and volumes are summarised in Table 3.

\subsection{Instruments and settings}

\subsubsection{Mineralogical analysis}

In order to assess the mineralogy of the samples, we conducted analyses using mid-infrared spectroscopy, Raman spectroscopy, Xray powder diffraction and optical microscopy in polarised light. Petrographic observations were conducted for understanding the heat treatment related characteristics of the samples. A complete petrographic evaluation of these samples lies beyond the scope of this work. Crystal sizes were measured using a screw micrometre eyepiece at the highest magnification. Mid-infrared transmission spectra were acquired by means of direct transmission through the polished slabs cut from the samples, using unpolarised radiation. Spectra were recorded between $4000 \mathrm{~cm}^{-1}$ and $2500 \mathrm{~cm}^{-1}$ with a spectral resolution of $4 \mathrm{~cm}^{-1}$ using a Bruker VECTOR $22 \mathrm{spec}-$ trometer. The obtained spectra show the $\mathrm{OH}$ region allowing for the 
Table 1

Mineral determination obtained from mid-infrared spectroscopy, Raman spectroscopy and X-ray powder diffraction.

\begin{tabular}{|c|c|c|c|c|c|c|c|c|c|c|c|}
\hline \multirow[t]{2}{*}{ Sample nr } & \multicolumn{3}{|l|}{ Raman } & \multirow{2}{*}{$\frac{\text { IR reflectivity }}{\text { Quartz }}$} & \multicolumn{3}{|c|}{ IR transmission } & \multicolumn{4}{|l|}{ XRD } \\
\hline & Quartz & Anatase & Clay & & Illite & Kaolinite & Other & Quartz & Anatase & Microcline & Illite \\
\hline SA-11-2 & $\mathrm{X}$ & $\mathrm{X}$ & $\mathrm{X}$ & $100 \%$ & & Traces & & $98 \%$ & $1 \%$ & Traces & \\
\hline SA-11-10A & $\mathrm{X}$ & $\mathrm{X}$ & $\mathrm{X}$ & $100 \%$ & & & & $98 \%$ & $1 \%$ & Traces & \\
\hline SA-11-12A & $\mathrm{X}$ & $\mathrm{X}$ & $\mathrm{X}$ & $100 \%$ & Traces & & & & & & \\
\hline SA-11-17A & $\mathrm{X}$ & $\mathrm{X}$ & $\mathrm{X}$ & $100 \%$ & & & & $98 \%$ & $1 \%$ & $1 \%$ & \\
\hline SA-11-22A & $\mathrm{X}$ & $\mathrm{X}$ & $\mathrm{X}$ & $100 \%$ & & & & & & & \\
\hline SA-11-22B & $\mathrm{X}$ & $\mathrm{X}$ & $\mathrm{X}$ & $100 \%$ & & Traces & & & & & \\
\hline SA-11-36 & $\mathrm{X}$ & $\mathrm{X}$ & $\mathrm{X}$ & $100 \%$ & Traces & & Amphibole & $98 \%$ & $1 \%$ & Traces & Traces \\
\hline SA-11-56 & $\mathrm{X}$ & $\mathrm{X}$ & $\mathrm{X}$ & $100 \%$ & & & & & & & \\
\hline SA-11-56b & $\mathrm{X}$ & $\mathrm{X}$ & $\mathrm{X}$ & $100 \%$ & Traces & & & $97 \%$ & $2 \%$ & $1 \%$ & \\
\hline SA-11-61F & $\mathrm{X}$ & $\mathrm{X}$ & $\mathrm{X}$ & $100 \%$ & & & & & & & \\
\hline SA-11-65B & $\mathrm{X}$ & $\mathrm{X}$ & $\mathrm{X}$ & $100 \%$ & & & & $97 \%$ & $2 \%$ & Traces & Traces \\
\hline
\end{tabular}

assessment of hydroxylated phyllosilicates (i.e. clay). Mid-infrared reflectivity spectra were acquired on the surface of the slabs, using the same spectrometer. Reflection data was collected between $2000 \mathrm{~cm}^{-1}$ and $350 \mathrm{~cm}^{-1}$ with a $2 \mathrm{~cm}^{-1}$ spectral resolution, an incidence of $45^{\circ}$ and unpolarised radiation. These spectra show the lattice vibrations of the minerals forming the samples. Additionally, Raman spectra were acquired on the surface of the same polished slabs using a Horiba Jobin Yvon HR800 spectrometer equipped with edge filters. Spectra were recorded between $50 \mathrm{~cm}^{-1}$ and $1200 \mathrm{~cm}^{-1}$. The exciting wavelength was the $514 \mathrm{~nm}$ line of an $\mathrm{Ar}^{+}$laser that, in combination with a 2400 lines $/ \mathrm{mm}$ grating, results in a spectral resolution better than $0.5 \mathrm{~cm}^{-1}$. Spectrometer calibration was set using the $520.5 \mathrm{~cm}^{-1}$ band of a Si crystal. A $10 \times$ objective, producing an exciting spot of approximately $10 \mu \mathrm{m}$, was used for spectral acquisition. In addition to the infrared and Raman data, X-ray powder diffraction data was collected from six of the samples (see Table 1) before heating using a Bruker D2 PHASER diffractometer. Diffraction diagrams were recorded between 0 and $65^{\circ} 2 \theta$ with a step size of 0.2 s/degree (using the $\mathrm{K}_{\alpha}$ line of a $\mathrm{Cu}$ anode, no incident beam monochromator). The sample holder was in constant rotation during acquisition.

\subsubsection{Analysis of the heat induced transformations}

The sample's $\mathrm{H}_{2} \mathrm{O}$ and $\mathrm{SiOH}$ content as a function of the annealing temperature was measured by means of near infrared (NIR) spectroscopy. NIR transmission spectra were recorded at normal incidence between 5500 and $4100 \mathrm{~cm}^{-1}$ with a resolution of $8 \mathrm{~cm}^{-1}$, using the same Bruker Vector 22 spectrometer and unpolarised radiation. A circular aperture of $12 \mathrm{~mm}$ diameter delimited the analysed area on the slabs. Due to the relatively high opacity of the silcrete samples, spectral acquisition was repeated 500 times in order to obtain spectra with a sufficiently good signal/noise ratio. This ratio still being low, we also acquired NIR spectra of all samples in the same spectral region using a Varian Cary 5000 UV-Vis-NIR-Spectrometer in diffuse reflection mode on powders with random orientation (spectral resolution $1 \mathrm{~nm}$, scan rate $600 \mathrm{~nm} / \mathrm{min}$ ). These diffuse reflection spectra do not yield quantitative information but have a significantly better signal/noise ratio. The transmission spectra were then numerically smoothed for data extraction (the comparison with untreated diffusion spectra helped to avoid excessive smoothing). The quantitative determination of the silanole and molecular water contents was calculated from the smoothed transmission spectra using the molar absorption coefficients given by Scholze (1960). $\mathrm{H}_{2} \mathrm{O}$ concentrations were determined using the linear absorption coefficient $\alpha=1.14 \mathrm{~L} / \mathrm{mol} \mathrm{cm}$ measured at $5430 \mathrm{~cm}^{-1}$ and $\mathrm{SiOH}$ concentrations were calculated using the integral absorption coefficient $\alpha=160 \mathrm{~L} / \mathrm{mol} \mathrm{cm}{ }^{2}$ as discussed in Schmidt et al. (2011). Baselines for absorbance measurements of the two combination bands $\left(\mathrm{H}_{2} \mathrm{O}\right.$ at $5430 \mathrm{~cm}^{-1}$ and $\mathrm{SiOH}$ at $\left.4547 \mathrm{~cm}^{-1}\right)$ were straight lines between the two lowest points on either side of the absorption bands and are shown in Fig. 4. Error bars for the measured absorptions of a given sample were calculated by repeating spectral acquisition 30 times on one sample and performing the smoothing process independently. These errors were found to be mainly a function of the signal/noise ratio (influenced by the overall opacity of the slabs) and the sample homogeneity at different spots across the slabs.

In addition to the NIR measurements, the weight loss as a function of heating temperature was measured using a SETARAM Setsys Evolution thermo balance. The heat transfer was significantly increased using a platinum crucible and helium atmosphere allowing for better measurement accuracy. Curves were recorded between 40 and $1000{ }^{\circ} \mathrm{C}$ with a heating rate of $1^{\circ} \mathrm{C} / \mathrm{min}$.

For maximum tolerated heating speed measurements, a Thermolyne 47900 electrical furnace with free access to oxygen was used.

Table 2

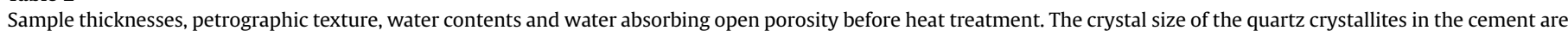

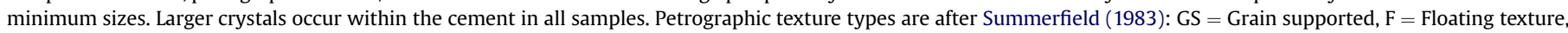
$\mathrm{M}=$ Matrix dominated and $\mathrm{C}=$ Conglomeratic.

\begin{tabular}{|c|c|c|c|c|c|c|c|}
\hline Sample $\mathrm{Nr}$ & Thickness & $\mathrm{H}_{2} \mathrm{O}_{\text {structure }}(\mathrm{wt} \%)$ & $\mathrm{SiOH}(w t \%)$ & $\mathrm{H}_{2} \mathrm{O}_{\text {porosity }}(\mathrm{wt} \%$ ) & Vol\% of clasts & Crystal size cement & Petrographic texture type \\
\hline SA-11-02 & $464 \pm 5 \mu \mathrm{m}$ & 0.156 & 0.16 & 0.134 & 50 & $\approx 12 \mu \mathrm{m}$ & GS \\
\hline SA-11-10A & $466 \pm 5 \mu \mathrm{m}$ & 0.012 & 0.162 & 0.31 & 15 & $\approx 20 \mu \mathrm{m}$ & $\mathrm{F}$ \\
\hline SA-11-12A & $469 \pm 5 \mu \mathrm{m}$ & 0.014 & 0.189 & 0.186 & 10 & $\approx 25 \mu \mathrm{m}$ & $\mathrm{F}$ \\
\hline SA-11-17A & $502 \pm 5 \mu \mathrm{m}$ & 0.013 & 0.137 & 0.23 & 40 & $\approx 7 \mu \mathrm{m}$ & GS \\
\hline SA-11-22A & $400 \pm 5 \mu \mathrm{m}$ & 0.007 & 0.106 & 0.115 & 15 & $\approx 15 \mu \mathrm{m}$ & $\mathrm{F}$ \\
\hline SA-11-22B & $435 \pm 5 \mu \mathrm{m}$ & 0.045 & 0.632 & 1.136 & 5 & $\approx 12 \mu \mathrm{m}$ & M \\
\hline SA-11-36 & $515 \pm 5 \mu \mathrm{m}$ & 0.078 & 0.86 & 1.479 & 10 & $<5 \mu \mathrm{m}$ & $\mathrm{F}$ \\
\hline SA-11-56 & $524 \pm 5 \mu \mathrm{m}$ & 0.039 & 0.378 & 0.604 & 10 & $\approx 9 \mu \mathrm{m}$ & $\mathrm{C}$ \\
\hline SA-11-56b & $416 \pm 5 \mu \mathrm{m}$ & 0.038 & 0.199 & 0.305 & 60 & $\approx 11 \mu \mathrm{m}$ & C \\
\hline SA-11-61F & $464 \pm 5 \mu \mathrm{m}$ & 0.018 & 0.179 & 0.375 & 15 & $\approx 20 \mu \mathrm{m}$ & $\mathrm{F}$ \\
\hline SA-11-65B & $500 \pm 5 \mu \mathrm{m}$ & 0.016 & 0.229 & 0.585 & 50 & $<5 \mu \mathrm{m}$ & GS \\
\hline
\end{tabular}


Table 3

Silcrete samples abruptly exposed to $550{ }^{\circ} \mathrm{C}$ without ramp rate and results of their knappability after this treatment.

\begin{tabular}{lrrll}
\hline Sample Nr & Mass $(\mathrm{g})$ & Volume $\left(\mathrm{cm}^{3}\right)$ & $\begin{array}{l}\text { Heat induced } \\
\text { fractures observed }\end{array}$ & Knappable \\
\hline SA-11-2 & 18.5 & 7.1 & No & Yes \\
SA-11-10A & 69.7 & 26.8 & No & Yes \\
SA-11-12A & 70.5 & 27.1 & No & Yes \\
SA-11-22A & 204.4 & 78.6 & No & Yes \\
SA-11-22B & 20.3 & 7.8 & No & Yes \\
SA-11-36 & 83.7 & 32.2 & Yes & No \\
SA-11-65 & 114.6 & 44.1 & No & Yes \\
\hline
\end{tabular}

\subsection{Experiments for the thermal analyses}

The analyses presented here are based on an approach elaborated by Schmidt et al. (2011) and Schmidt et al. (2012b) using near infrared spectroscopy and an experimental protocol aiming to reproduce heat treatment at different temperatures. The sample slabs were subjected to heat treatment in an electrical furnace using different temperatures: $110^{\circ} \mathrm{C}, 150^{\circ} \mathrm{C}, 200^{\circ} \mathrm{C}, 250^{\circ} \mathrm{C}, 300^{\circ} \mathrm{C}$,
$350{ }^{\circ} \mathrm{C}, 400{ }^{\circ} \mathrm{C}, 450{ }^{\circ} \mathrm{C}, 500{ }^{\circ} \mathrm{C}, 550{ }^{\circ} \mathrm{C}$ and $600{ }^{\circ} \mathrm{C}$. Although the expected transformations are essentially completed after 50 min of annealing at a given temperature (Fukuda and Nakashima, 2008; Schmidt et al., 2012b), samples were held at each of these temperatures for $2 \mathrm{~h} 30 \mathrm{~min}$. NIR spectra were recorded in the 'dehydrated state' immediately after the samples had cooled to room temperature. The samples were then rehydrated in deionised $\mathrm{H}_{2} \mathrm{O}$ for $24 \mathrm{~h}$ (at $21{ }^{\circ} \mathrm{C}$ and 1 bar) and a second spectrum was acquired in the 'hydrated state'. After this, the samples were heated to the next higher temperature and the measuring protocol was repeated. The ramp rate for all temperature steps was $20^{\circ} \mathrm{C} / \mathrm{min}$. This relatively fast heating rate could be sustained for all of the annealing temperatures used in the experiment. No heat induced fracturing, crazing or cracking was observed during the experiments.

This experimental protocol results in three values: [1] the concentration of water strongly retained in the rocks structure $\left(\mathrm{H}_{2} \mathrm{O}_{\text {structure }}\right)$, [2] the silanole $(\mathrm{SiOH})$ concentration and [3] the concentration of water loosely held in the network of inter-

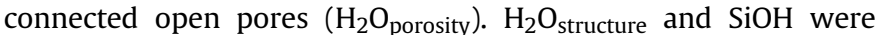
determined in the dehydrated state. $\mathrm{H}_{2} \mathrm{O}_{\text {porosity }}$ was measures by
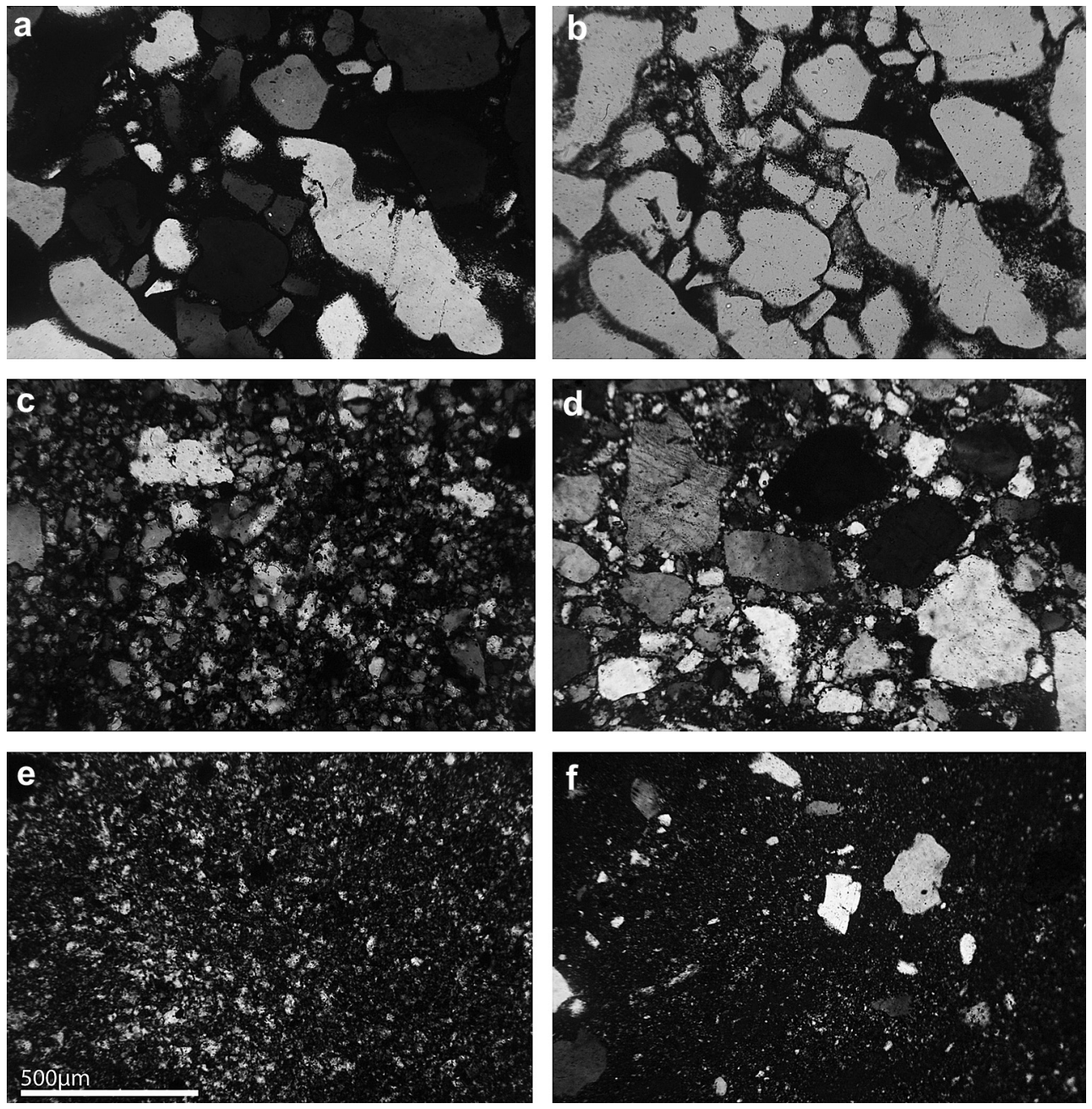

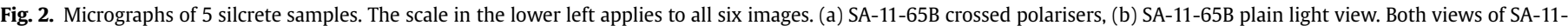

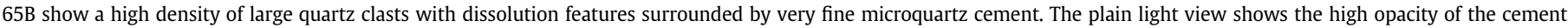

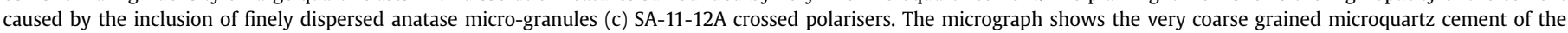

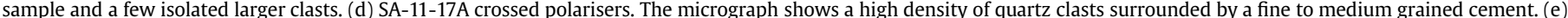

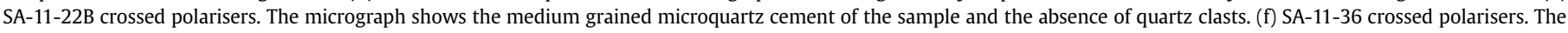
micrograph shows some isolated quartz clasts surrounded by a very fine grained cement. 


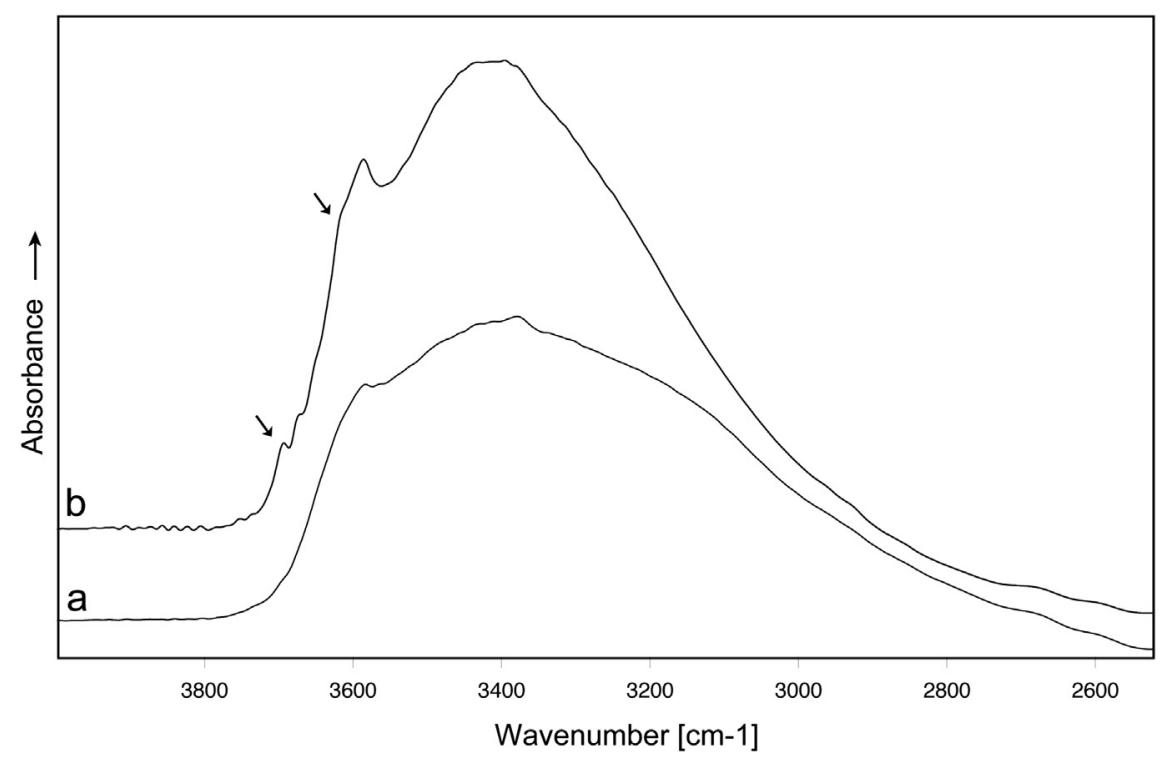

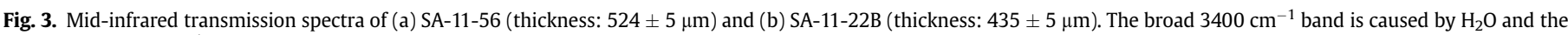

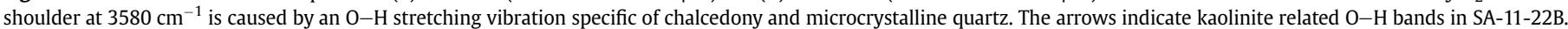
Spectra displaced vertically.

subtracting the $5430 \mathrm{~cm}^{-1} \mathrm{H}_{2} \mathrm{O}$ band's absorption in the dehydrated state spectra from the band's absorption in the hydrated state spectra. This value corresponds to water absorbed by open pores of the rock.

The experimental setup for the maximum tolerated heating speed measurements was as follows. The electrical furnace was preheated to $550{ }^{\circ} \mathrm{C}$. Once this temperature reached, the furnace door was opened as fast as possible for a sample to be put in and then closed again. Because opening of the door caused a temperature drop of approximately $10{ }^{\circ} \mathrm{C}$, it was waited until the thermocouple showed again $550{ }^{\circ} \mathrm{C}$ before introducing the next sample in the furnace (approx. 2-3 min). Once all seven samples in the furnace, the temperature was held for $2 \mathrm{~h}$. After this, the furnace cooled down to room temperature (taking approx. $5 \mathrm{~h}$ ) before the samples were inspected and a flake was stuck from each of them so that a possible deterioration due to overheating could be evaluated.

\section{Results}

\subsection{Mineralogy and petrography of the samples}

Petrographic observation of the thin sections reveals the texture of the samples. All samples are totally silicified and contain large quartz grains, measuring from 0.2 to $2 \mathrm{~mm}$ (clasts), in varying proportions. Evaluated volume percentages of clasts in the rocks are summarised in Table 2. All 4 petrographic texture types described by Summerfield (1983) (GS = Grain supported, $\mathrm{F}=$ Floating, $\mathrm{M}=$ Matrix dominated and $\mathrm{C}=$ Conglomeratic) can be found in the samples (Table 2). The clasts are surrounded by a cement of microquartz of varying grain size (Fig. 2). The grain size of this cement is heterogeneous. Two samples show very fine grained cement with a grain size significantly below $5 \mu \mathrm{m}$, appearing almost isotropic under crossed polarisers (SA-11-36 and $-65 \mathrm{~B})$. Most samples show cement with a grain size between 10 and $20 \mu \mathrm{m}$ (Table 2 ). The cement of all samples contains finely dispersed micro-inclusions of yellowish-brown granules with a grain size near $1 \mu \mathrm{m}$. Raman spectroscopy and x-ray diffraction suggest the granules to consist of anatase $\left(\mathrm{TiO}_{2}\right)$. Their concentration seems higher in the finer grained parts of the cements. Other minerals like
K-feldspar, biotite, zircon and amphibole are very scarce. Only Kfeldspar is present as crystals with a size comparable to the quartz clasts, other minerals are significantly smaller.

The mid-infrared reflectance spectra show quartz to be the only phase in all samples. No auxiliary phase can be detected using this technique. However, this method is able to detect minor constituents of a sample only if these cause infrared bands at frequencies different from the major phase of the samples. It is noteworthy that no band at $555 \mathrm{~cm}^{-1}$, characteristic of non-bridging $\mathrm{Si}-\mathrm{O}$ in silanole (Schmidt and Fröhlich, 2011), was observed in the samples. This suggests the very low hydroxylation of South African silcrete samples.

The 11 mid-infrared transmission spectra show a broad absorption band at $3400 \mathrm{~cm}^{-1}$ caused by $\mathrm{H}_{2} \mathrm{O}$ and a shoulder at $3580 \mathrm{~cm}^{-1}$ caused by an $\mathrm{O}-\mathrm{H}$ stretching vibration commonly found in micro- to cryptocrystalline quartz (Kronenberg, 1994) (Fig. 3). Five of the spectra also show weak $\mathrm{O}-\mathrm{H}$ stretching bands caused by clay (Table 1, Fig. 3). The observed shoulders, caused by single $\mathrm{O}-\mathrm{H}$ stretching bands at $3619 \mathrm{~cm}^{-1}$, are consistent with clay species like illite and members of the smectite group (i.e. montmorillonite). Two other samples show traces of kaolinite or other 1:1 clay minerals indicated by two $\mathrm{O}-\mathrm{H}$ stretching bands at $3695 \mathrm{~cm}^{-1}$ and $3619 \mathrm{~cm}^{-1}$. One sample (SA-11-36) shows traces of an amphibole related $\mathrm{OH}$ stretching vibration at $3675 \mathrm{~cm}^{-1}$.

These results are corroborated by Raman spectroscopy. All samples show the characteristic bands of quartz and an additional week broad band near $850 \mathrm{~cm}^{-1}$ consistent with a clay impurity. Furthermore, anatase $\left(\mathrm{TiO}_{2}\right)$ can be detected in all samples through its characteristic bands at $145 \mathrm{~cm}^{-1}, 397 \mathrm{~cm}^{-1}, 514 \mathrm{~cm}^{-1}$ and $639 \mathrm{~cm}^{-1}$. Although the micro-Raman analyses are not quantitative, they nonetheless show the great homogeneity of all analysed silcrete samples that are composed of quartz with anatase and a minor clay impurity. Furthermore, the quantitative mid-infrared data allow for evaluating the quantity of clay in the samples. Based on the thickness of the slabs and the relative intensity of the clay related $\mathrm{O}-\mathrm{H}$ bands, the quantity of phyllosilicates can be estimated to be less than one percent in all samples. No band near $500 \mathrm{~cm}^{-1}$, indicating moganite or non-bridging $\mathrm{Si}-\mathrm{O}$ in silanole (Schmidt et al., 2012a), could be observed. 


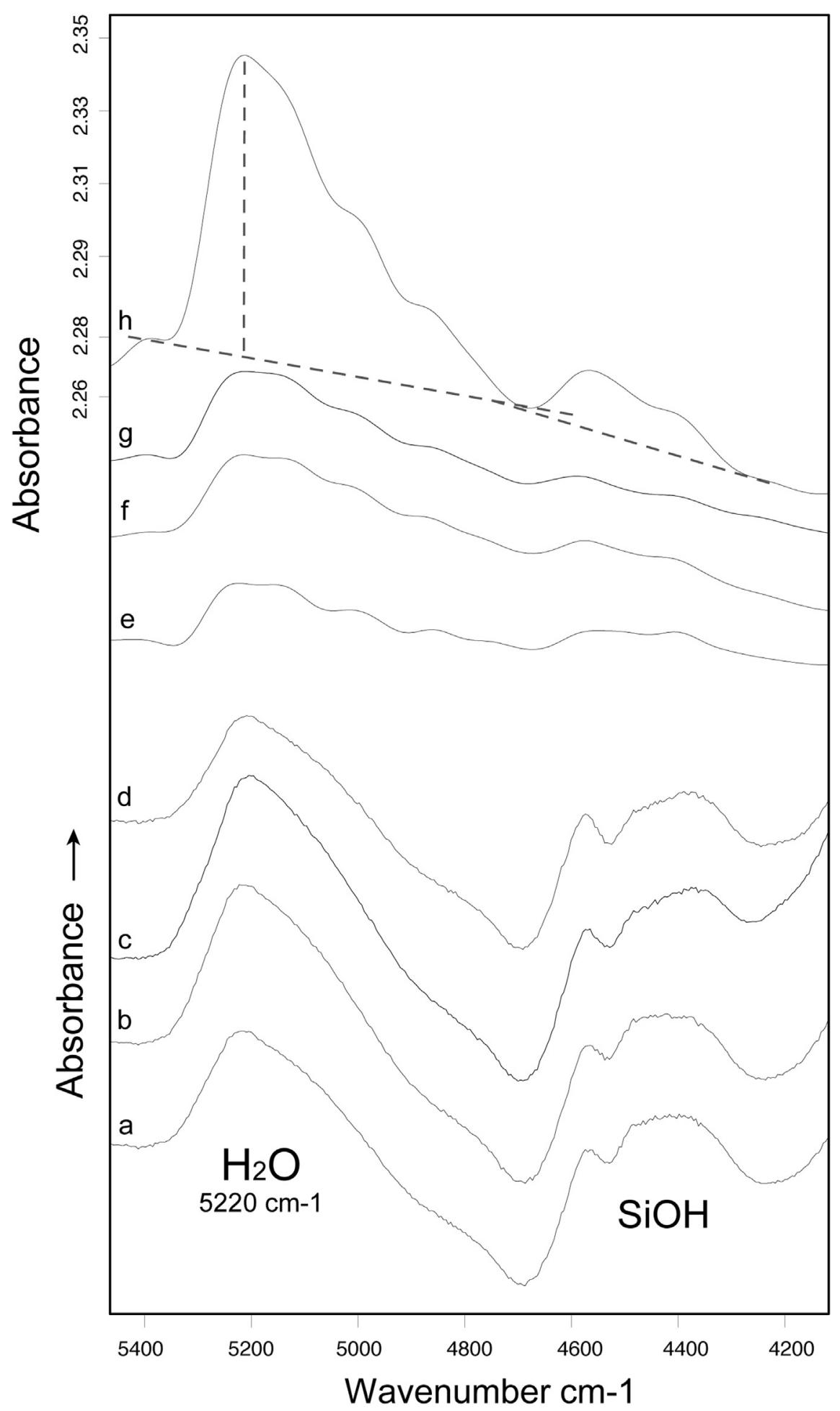

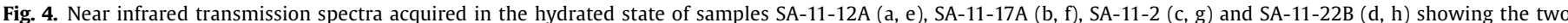

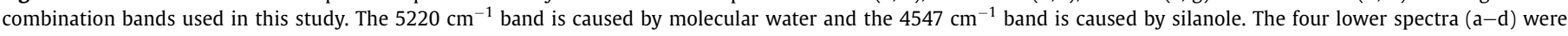

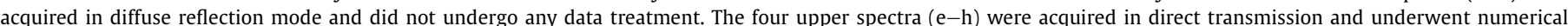

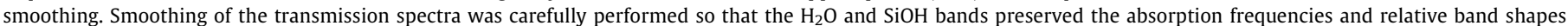

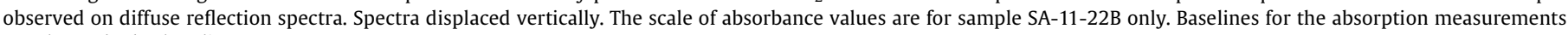
are shown by broken lines.

In order to obtain semi-quantitative information about the anatase content, six samples were analysed using XRD. Diffraction data shows quartz to be the major phase of the samples with up to $98 \%$. Anatase was detected with up to $2 \%$. XRD cannot be used for semi-quantitative determinations of phyllosilicates with an unknown orientation. However, it confirms one of the observed clay minerals in the analysed samples to be illite. An additional minor amount of K-feldspar (microcline) can also be 
detected but does not account for more than one percent of the samples. The powder diffractograms do not show any moganite peaks. These results are summarised in Table 1.

\subsection{Temperature induced transformations in silcrete}

\subsection{1. $\mathrm{SiOH}$ and $\mathrm{H}_{2} \mathrm{O}$ before heat treatment}

Despite relatively large error bars caused by the overall weak concentrations of silanole and molecular water in the silcrete samples, the assessment of the NIR combination bands' absorptions shows coherent results. Fig. 4 shows spectra of 4 samples in the frequency range of the analysed NIR combination bands. The figure also allows for a comparison between high-resolution diffuse reflection spectra and quantitative transmission spectra used for 'water' content measurement. As can be expected, quantitative transmission spectra yield less detail than diffuse reflection spectra and the determined absorption values may yield errors in the magnitude of the error bars in Figs. 5-7. Concentrations of $\mathrm{H}_{2} \mathrm{O}_{\text {structure, }} \mathrm{SiOH}$ and $\mathrm{H}_{2} \mathrm{O}_{\text {porosity }}$ before heat treatment are summarised in Table 2 . It can be noticed that the $\mathrm{H}_{2} \mathrm{O}_{\text {structure }}$ content is relatively low in all samples. The structural water concentrations of the samples are 25-70 times lower than the values known for length-fast chalcedony and flint (Schmidt et al., 2011, 2012b; Flörke et al., 1982; Graetsch et al., 1985). Concerning the $\mathrm{SiOH}$ contents, the samples can be separated into two groups. Samples SA-11-22B and SA-11-36 show silanole contents comparable to those of flint (Schmidt et al., 2011) whereas the rest of the samples show $\mathrm{SiOH}$ contents between 2 and 6 times lower than those of flint. Both samples with high $\mathrm{SiOH}$ content show up to 4 times higher values of $\mathrm{H}_{2} \mathrm{O}_{\text {porosity }}$ than flint (Schmidt et al., 2011, 2012b). The 9 other samples show values of water absorbing open porosity comparable with flint or slightly lower. These values indicate a significantly higher open porosity/ silanole ratio for all silcrete samples than known from flint and chert. The silanole concentration shows no correlation with the petrographic texture type. However, a correlation between silanole concentration and grain size of the cement together with the percentage of larger clasts is noticeable. Samples with finer grained cement and/or fewer clasts contain more SiOH than samples with coarser grained cement and a higher density of clasts.

\subsubsection{Thermal behaviour}

All samples lost silanole upon heat treatment. Fig. 5 shows two plots illustrating this tendency, one of a sample with a low $\mathrm{SiOH}$ concentration (Fig. 5a) and one of a sample with a silanole concentration comparable to flint (Fig. 5b). Silanole is lost at temperatures higher than $200-300{ }^{\circ} \mathrm{C}$. The processes governing silanole loss seem therefore to be the same as in LF-chalcedony and flint (Schmidt et al., 2011, 2012b). Some silanole is retained until $600{ }^{\circ} \mathrm{C}$.

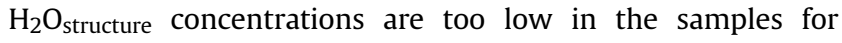
determining any evolution. Fig. 6 shows the error bars to be too large for the evaluation of any tendency in the structural water contents of the silcrete samples.

The $\mathrm{H}_{2} \mathrm{O}_{\text {porosity }}$ measurements show the heat induced reduction of water absorbing open pores. Fig. 7 shows two plots of the pore water concentration as a function of different annealing temperatures for two samples, one with an initial pore volume comparable to flint (Fig. 7a) and one with a $4 \times$ higher initial pore volume (Fig. 7b). In the two samples with high silanole content, a first loss can be observed below $200{ }^{\circ} \mathrm{C}$. This first loss at low temperatures does not correspond to a true loss of porosity. It can be explained by the progressive dehydration of a very fine part of the porosity between $100{ }^{\circ} \mathrm{C}$ and $200{ }^{\circ} \mathrm{C}$ that cannot easily be rehydrated (Schmidt, 2011). This loss is not observed in samples with lower silanole content. The loss of porosity becomes evident at temperatures higher than $400{ }^{\circ} \mathrm{C}$ in all silcrete samples. Only a faint loss of porosity can be noticed at lower temperatures. The total lost volume, even at high temperatures, is small if compared to flint (Schmidt et al., 2011, 2012b). In order to obtain a porosity reduction between $60 \%$ and $80 \%$, the heating temperature has to attain at least $500{ }^{\circ} \mathrm{C}$ in all samples. Unlike pure LF-chalcedony, none of the silcrete samples was completely devoid of open porosity after heat treatment to $600{ }^{\circ} \mathrm{C}$.

TG curves of samples SA-11-12A and SA-11-36 and their derivatives are shown in Fig. 8 . The curves show a total weight loss of $\approx 0.22 \%$ and $\approx 0.6 \%$ respectively which is consistent with the sample's silanole concentration as determined by the NIR measurements. Mass is continuously lost throughout the studied temperature range. However, the curves of both samples show an intermediary temperature range between $400{ }^{\circ} \mathrm{C}$ and $550{ }^{\circ} \mathrm{C}$ where almost no mass is lost. NIR data indicates that the porosity loss in both samples is strongest in this temperature range (Fig. 7). The direct comparison between the TG curve's derivatives and the NIR open porosity values shows a good correlation between pore loss and the intermediate temperature range where almost no mass is lost (grey area in Fig. 8c and d). This strongly indicates that the closure of open pores in the analysed silcrete samples is mainly due to factors that do not involve the departure of mass (i.e. unlike flint, silanole loss is not the sole cause of the silcrete's structural transformations upon heat treatment).

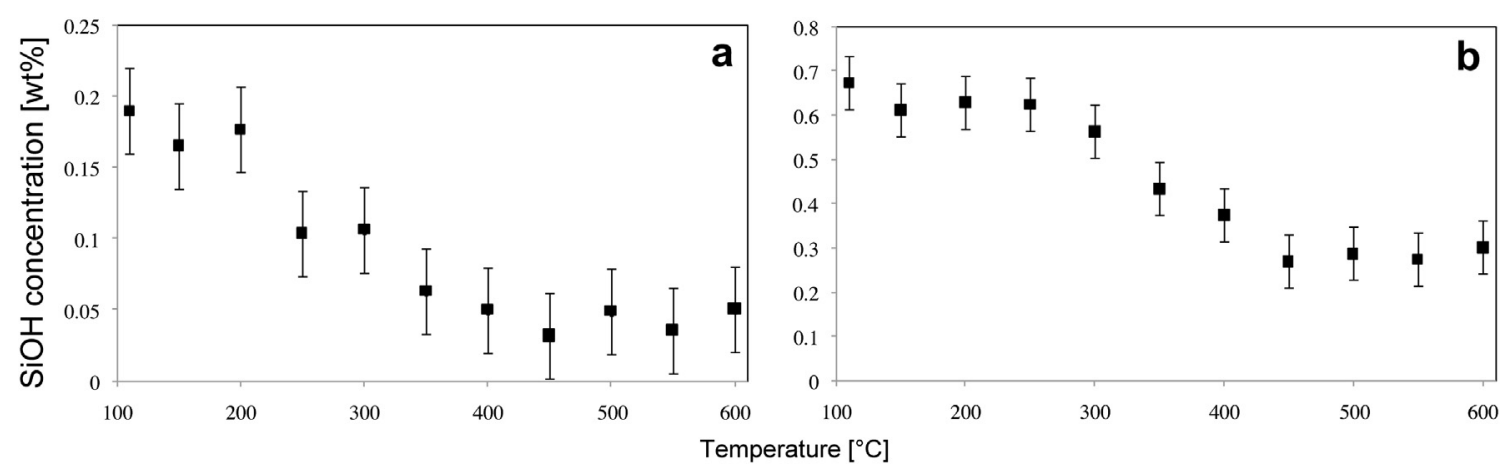

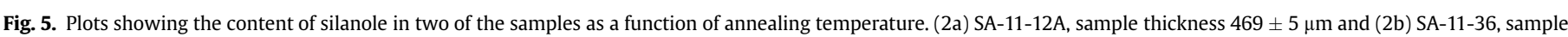

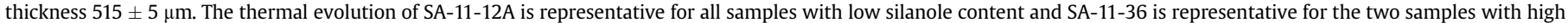

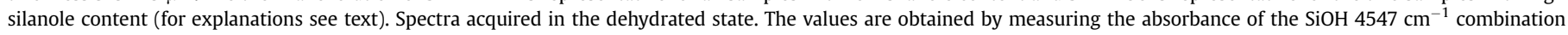
band. Silanole loss begins between $200{ }^{\circ} \mathrm{C}$ and $300{ }^{\circ} \mathrm{C}$. 


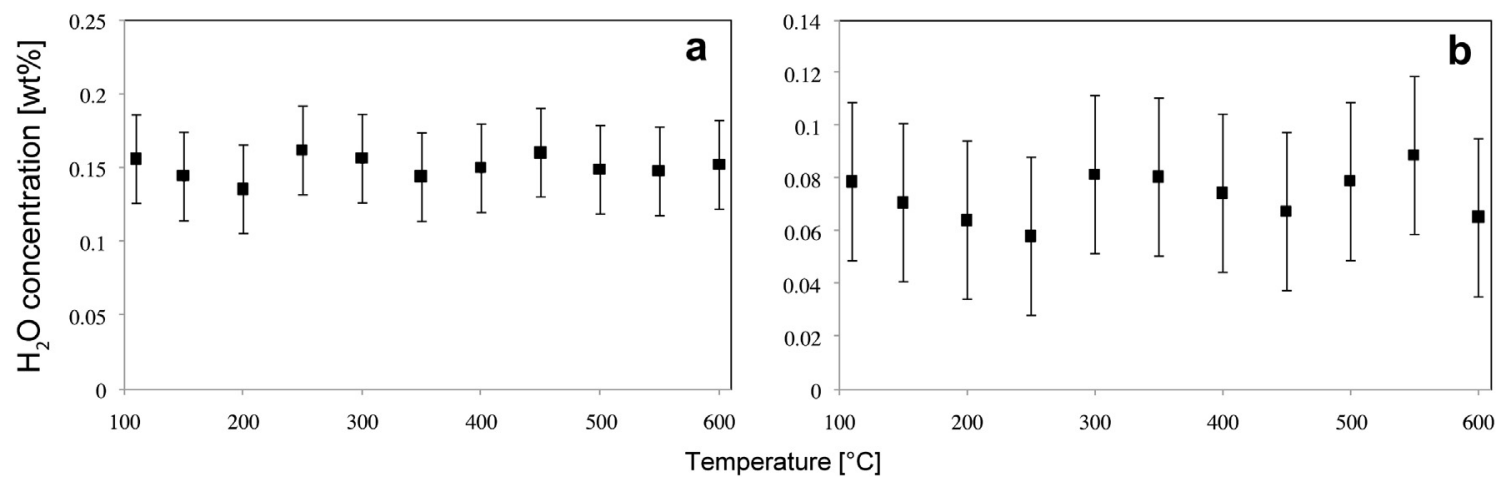

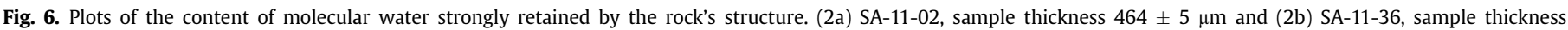

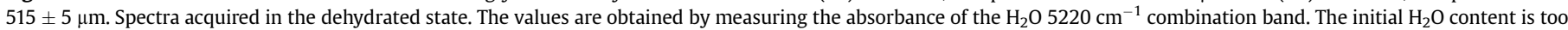
low and the calculated errors are too large for a clear evolution to be noticed from these measurements.

\subsubsection{Maximum tolerated heating speed}

Upon placing the silcrete samples in a furnace preheated to $550{ }^{\circ} \mathrm{C}$, only one of the seven samples showed traces of overheating (Table 3). SA-11-36 showed several fractures and was judged useless for tool production after this treatment. The other six samples, however, did not show any heat induced fracturing, crazing or other form of deterioration. It was possible to detach a clean flake from all of them. Even though SA-11-22B and SA-11-36 both have silanole contents comparable to flint, only sample SA-1136 (the one with the highest $\mathrm{SiOH}$ content of all samples) showed a deterioration of its flaking quality after being subjected to this abrupt treatment. The other samples showed lower $\mathrm{SiOH}$ concentrations (compare with Table 2). This result suggests a good correlation between endured maximum heating speed, silanole content and porosity of the samples.

\section{Discussion}

The sample's mineralogical compositions and petrographic textures correspond to a variety of other types of silcrete from different parts of the world (Summerfield, 1983) and the obtained results on the studied samples' thermal transformations can most likely be transferred to a large number of silcrete from different origins. This is currently being verified for silcrete from different parts of South Africa.

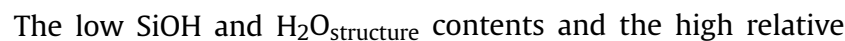
porosity volume as compared with LF-chalcedony and flint seem to be the main heat treatment relevant difference between South
African continental silcrete and marine sedimentary silica rocks (Schmidt et al., 2012b). These low 'water' contents can be explained by the different nature of the microcrystalline cement of both rocks. The analysed silcrete samples did not contain chalcedony but were made up of quartz clasts surrounded by a cement of micro-quartz. The relative abundance of macro-quartz clasts, devoid of hydroxyl defects, may also account for the low overall water content of the rocks. The sample's silanole concentration seems to be directly correlated to the size of the micro-quartz grains of the cement and the abundance of clasts. High $\mathrm{SiOH}$ samples display a fine micro-quartz cement whereas low $\mathrm{SiOH}$ samples show a somewhat 'coarser grained' cement. The relatively large pore volume of South African silcrete may be caused by voids and channels due to illuviation in the original sediment (Porraz et al., 2013) but also to pores and joints around clasts and structural elements in the rocks.

Our results show that the controlled treatment of IR transmission data (numerical smoothing) in combination with high resolution diffuse reflection spectroscopy for data treatment control is a good method for quantitative $\mathrm{H}_{2} \mathrm{O}$ and $\mathrm{SiOH}$ determinations in highly opaque sample. However, the results also show the limitations of NIR water determinations in silcrete by means of transmission. The structural water $\left(\mathrm{H}_{2} \mathrm{O}_{\text {structure }}\right)$ contents are too low in the $\approx 500 \mu \mathrm{m}$ thick sections for significant concentration values to be calculated. These low concentrations could be compensated for by thicker sections but the high opacity of the material does not allow spectral acquisition with longer optical pathways. This illustrates the need for further and more precise

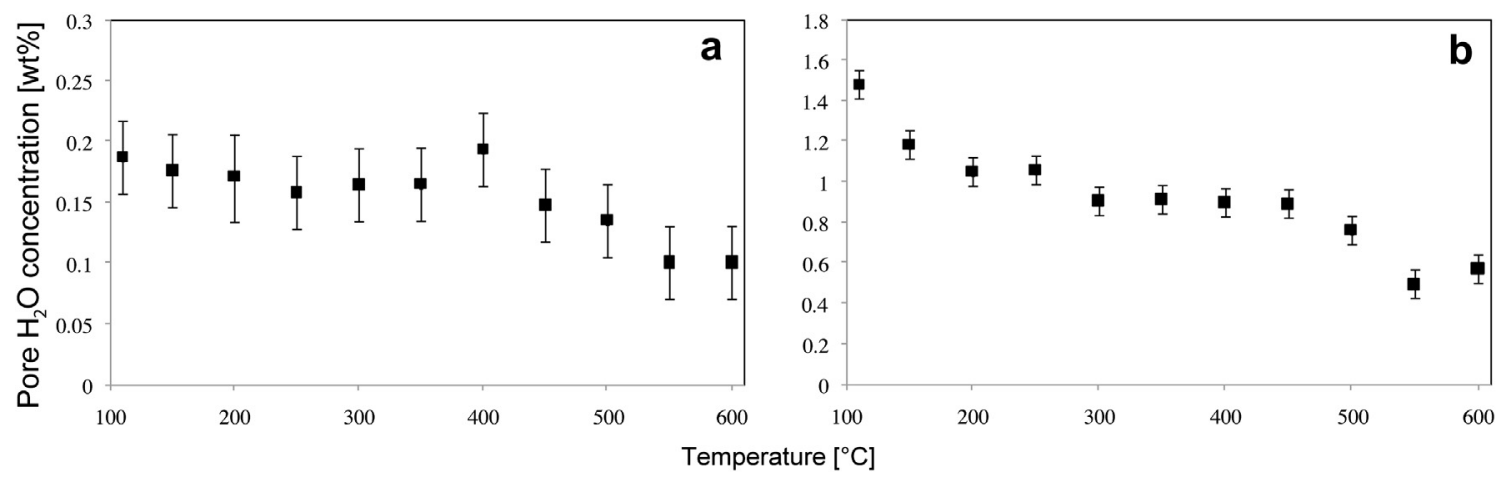

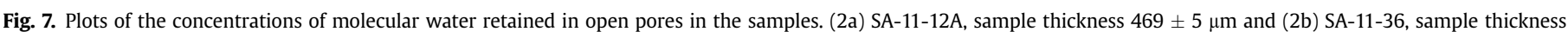

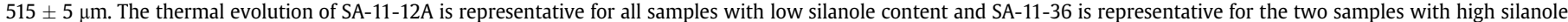

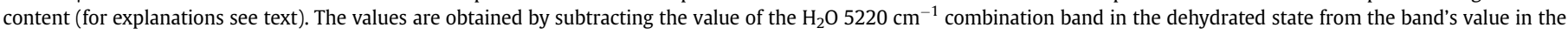
hydrated state. The disappearance of open pores becomes evident from $450{ }^{\circ} \mathrm{C}$ upward. 

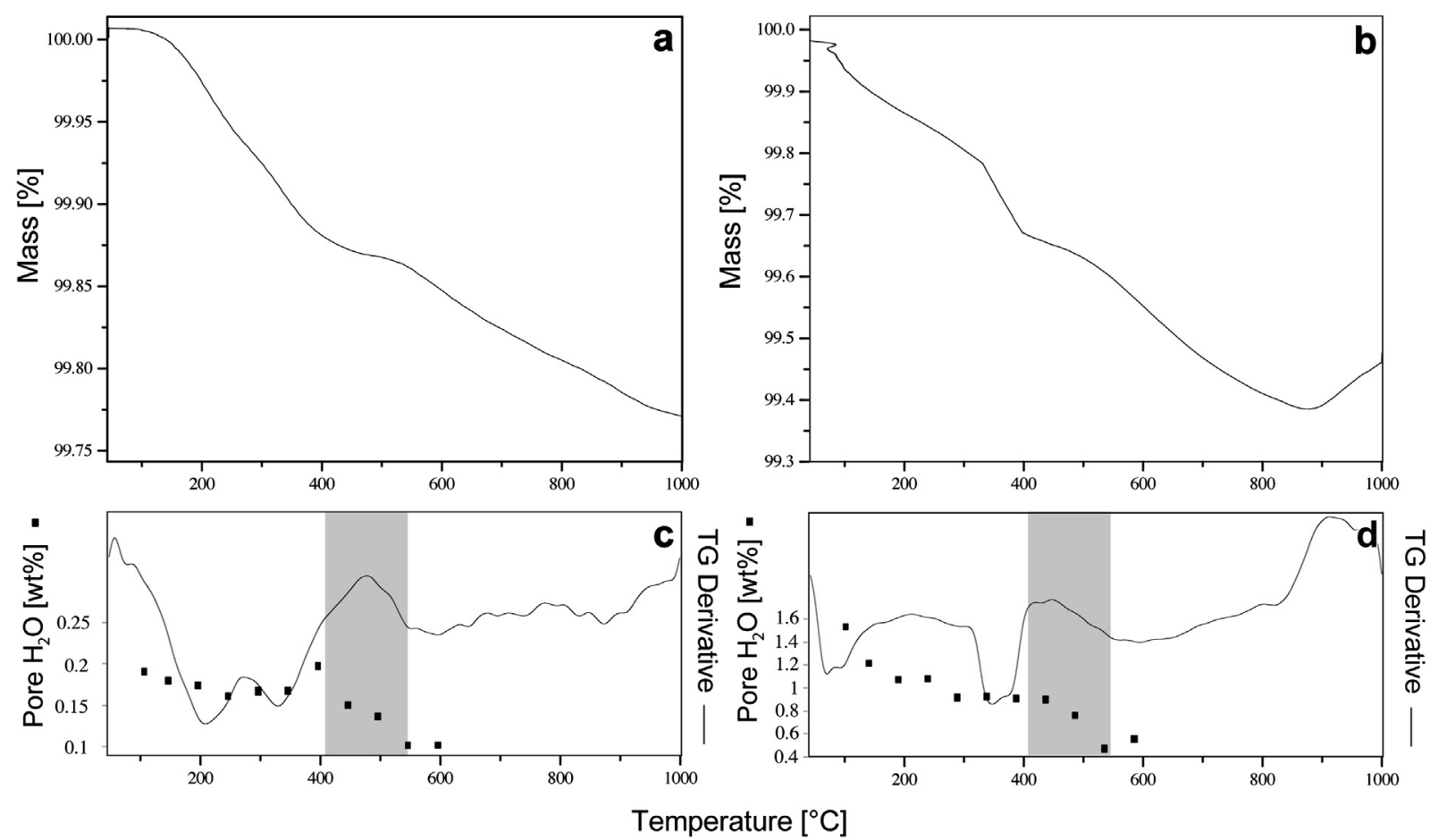

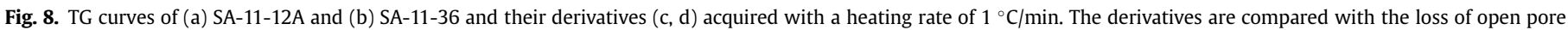

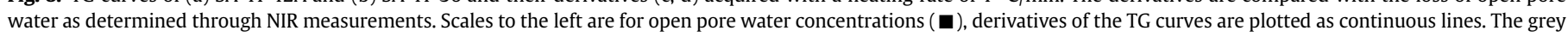
areas in $\mathrm{c}$ and $\mathrm{d}$ highlight the temperature intervals with the most pronounced pore loss of the samples. During this interval the samples loose almost no mass.

studies for investigating all the parameters and key temperatures of the silcrete's thermal transformations. However, our results show the major episodes and key temperatures of the heat induced transformations in silcrete:

(1) The first reaction of the material is the loss of silanole, starting at temperatures between $200{ }^{\circ} \mathrm{C}$ and $300{ }^{\circ} \mathrm{C}$. This is analogous to flint and other LF-chalcedony rich silica rocks. However, unlike flint, the majority of the molecular water created by this $\mathrm{SiOH} \rightarrow \mathrm{H}_{2} \mathrm{O}$ synthesis can be evacuated from the rock through a relatively large network of open pores. This reaction must be expected to contribute to the closing of a part of these pores but the volume of open pores remains high at these temperatures as compared to pure LF-chalcedony. The good evacuation of the produced $\mathrm{H}_{2} \mathrm{O}$ prevents fracturing of the silcrete even at rapid heating speeds. This loss of silanole and the closing of pores can be expected to cause the first transformation of the flaking properties between $200{ }^{\circ} \mathrm{C}$ and $400{ }^{\circ} \mathrm{C}$.

(2) Annealing temperatures have to attain $400{ }^{\circ} \mathrm{C}-500{ }^{\circ} \mathrm{C}$ for the volume of water absorbing pores to be reduced by $60 \%-80 \%$. This loss of porosity does not correspond to the formation of new bridging $\mathrm{Si}-\mathrm{O}-\mathrm{Si}$ bonds for it is not associated with a weight loss. It has to be explained by secondary constituents of the rocks accomplishing a transformation that results in the loss of porosity. A candidate for this pore closing reaction is the swelling of the anatase fraction in the rocks. Indeed, Wang et al. (2008) show a size increase of up to $20 \%$ for pure anatase particles subjected to a $500{ }^{\circ} \mathrm{C}$ heat treatment. The volume increase of the $1-2 \%$ anatase, finely distributed all over the cement of the rocks, may contribute to the loss of their pore volume. Since pore closing plays an important role in modifying the flaking properties of silica rocks (Schmidt et al., 2012b) and the strongest loss of porosity can be ascribed to this reaction, the ideal temperature for heat treatment of South African silcrete can be estimated to be between $400{ }^{\circ} \mathrm{C}$ and $500{ }^{\circ} \mathrm{C}$.
Even at heating temperatures as high as $600^{\circ} \mathrm{C}$, water created by the 'liberation' of silanole (Schmidt et al., 2011) can be evacuated though a network of open pores that remains present in the rock. In pure LF-chalcedony and flint, it is the synthesis of $\mathrm{H}_{2} \mathrm{O}$ within the rock, unable to be evacuated by open pores, that causes fracturing of the samples (Schmidt et al., 2012b). Differential thermal expansion of the quartz crystallites is unlikely to cause fracturing in micro-crystalline silica rocks at temperatures below $600{ }^{\circ} \mathrm{C}$. Both the linear and volumetric thermal expansion coefficients of $\alpha$ quartz are relatively low as compared to other natural materials (Sosman, 1927). The fact that none of our large silcrete samples with low $\mathrm{SiOH}$ content suffered fracturing, crazing or any other deterioration upon abrupt exposure to $550{ }^{\circ} \mathrm{C}$ corroborates the finding of Schmidt et al. (2012b) and Schmidt (2011) that the driving force of overheating in micro-crystalline silica rocks is not differential thermal expansion but increasing vapour pressure of fluid inclusions in the rocks. Even the largest volume tested did not show signs of overheating upon abrupt exposure to heat; indicating that heat induced fracturing of low-SiOH-silcrete is independent of volume in the range of the tested temperatures (until $550{ }^{\circ} \mathrm{C}$ ) and volumes (until $79 \mathrm{~cm}^{3}$ ). This corroborates the results of Mercieca and Hiscock (2008) who showed that silcrete can be rapidly heated until $600{ }^{\circ} \mathrm{C}$.

Thus, regardless of whether MSA hunter-gatherers benefitted from the formation of new $\mathrm{Si}-\mathrm{O}-\mathrm{Si}$ bonds or the loss of porosity caused by secondary minerals, the heating speed could be dramatically faster than for flint and the maximum temperature did not need to be controlled as carefully as for flint. However, whereas low-SiOH-silcrete is very tolerant to heating speed and temperature, heat treatment of larger blocks of high-SiOH-silcrete might require slightly more attention.

The role of the $<1 \%$ clay fraction in the samples remains to be investigated. If the dehydration of clay (illite and kaolinite) plays a role in the modification process of the mechanical properties of 
South African silcrete, the temperatures at which this reaction begins to be effective lie above $500{ }^{\circ} \mathrm{C}$. Furthermore, some of the observed transformations (i.e. the role of strongly retained water and the implications of the relatively voluminous network of porosity to the rock's flaking properties) still remain to be understood using a set of appropriate analyses. A complete research program on South African silcrete and its role in the emergence of heat treatment for tool production is currently being prepared.

\section{Implications for the emergence of heat treatment in the South African MSA}

These results have important implications for understanding the discovery and mastering of lithic heat treatment in the South African MSA. The identification of heat treatment in the MSA (Brown et al., 2009) has pushed the earliest occurrence of this practice several thousand years back from previous reports from the European Upper Palaeolithic (Tiffagom, 1998; Bordes, 1969). At present, these South African MSA hunter-gatherers seem to have been the first humans to intentionally modify lithic raw material for knapping.

There seems to be general agreement in the current literature that heat treatment is a sophisticated technology requiring advanced cognitive capacities and a complex socio-economic structure. Alongside blade production, geometric backed tools and pressure flaking, heat treatment may therefore be understood as a behavioural proxy marking a main step in the technological evolution of prehistoric societies. This seems to hold true for heat treatment of flint as it is known from the European Upper Palaeolithic and the Neolithic. Indeed, flint heat treatment is a rather complicated procedure. The maximal heating temperature and the ramp rate are functions of the volume of the rocks (Schmidt et al., 2012b) and larger volumes are rather complicated to heat-treat because water is not easily evacuated from the interior (Schmidt et al., in press; Léa, 2004). In order to succeed in the treatment, an environment that prevents the material from heating too rapidly and exceeding temperatures must be established and maintained (Crabtree and Butler, 1964; Schmidt et al., 2012b). This heating environment requires the makers to have an intimate knowledge of [1] the heated material's properties and its temperature induced modifications and [2] the control of fire and its thermal gradients in the material used for the heating environment (e.g. sand in the case of a sand bath).

However, heat treatment in the South African MSA was not performed for transforming flint but silcrete. In this preliminary study, we found major differences between the thermal properties of these two rocks. Silcrete needs to be heated to temperatures approximately $200{ }^{\circ} \mathrm{C}$ higher than flint and the temperatures at which silcrete experiences overheating (cracking, crazing, deterioration of its flaking quality) are significantly higher than for flint (Schmidt et al., 2012b). Heating rates for silcrete with low 'water' content can also be considerably faster. Thus, most South African silcrete demands a much less elaborate heating procedure. Due to these relatively high effective temperatures and the large temperature range that silcrete can endure, it seems likely that this early heat treatment involved the use of areas surrounding open fires or the use of slightly cooled embers that were isolated from an open fire (with an average temperature of $550^{\circ} \mathrm{C}$ ). This is especially true for silcrete with low 'water' contents as it was the case for most of our samples. The heating characteristics of this silcrete do not require the setup of a special heating environment, nor do they demand any more knowledge or investment than the heating of compound adhesives, as known from the South African MSA archaeological record (Wadley et al., 2009), or the use of fire for cooking. The experimental reproduction of heat treatment by
Brown et al. (2009), using a protocol based on very slow indirect heating of the samples to $350^{\circ} \mathrm{C}$ in a sand bath beneath a wood fire designed for this purpose, seems to be an over investment. Silcrete heat treatment may therefore not correspond to a particularly high investment, neither in time nor in resources, as proposed by these authors but it could have been a relatively rapid and easy step in the chaîne operatoire of the lithic production. However, a very small part of our samples (two) showed higher 'water' content that the rest. These specific types of silcrete may have required slightly more careful handling during heat treatment. Even though only the assessment of the 'water' content of the silcrete types actually used for heat treatment during the MSA will shed light on the question of the used procedures, we remind that high-SiOH-silcrete only represents a very small part of the silcrete types found in the West Coast area.

We therefore strongly disagree with the hypothesis that silcrete raw material became more abundant during the MSA because of the temporal abundance of firewood allowing supplementary fires required for the heat treatment of the silcrete (Brown and Marean, 2010). Our results indicate that silcrete does not require the setup of supplementary fires but that it can easily be performed on fires used for cooking, heating and other fire-related activities. Hence, it does not automatically represent a supplementary cost in terms of time or wood consumption. Moreover, no dramatic change in wood consumption can be seen in the Diepkloof archaeological record (Cartwright, 2013) whereas heated silcrete was found throughout the sequence. We believe that one driving factor alone cannot account for the variation of raw material provisioning strategies observed during the MSA.

We also showed that heat treatment of silcrete does not necessarily require a sophisticated knowledge of fire and the heated material. Even though the first heating evidence at Diepkloof coincides with an increase of silcrete raw material (Porraz et al., 2013), local quartzite was also heated (Tribolo et al., 2013). However, due to the absence of a surface gloss on the fracture negatives of heated quartzite artefacts, it is difficult to determine whether quartzite heat treatment took place before knapping or if the quartzite was simply burned after use. If it could be demonstrated that quartzite was also heated before knapping, this may suggest a somewhat opportunistic practise of heat treatment, hence that it did not hinge on the intimate knowledge of the rawmaterial and its transformations. This is because heat treatment of most types of quartzite is useless, for this metamorphic rock already lost all its silanole (if there had ever been some) by the influence of heat and pressure, hence no transformation of the material can be achieved like in chalcedony, flint and silcrete (Schmidt et al., 2011, 2012b). However, this hypothesis needs further investigation and discussion.

The current archaeological data shows that the importance of heat treatment varied throughout time. Heat treatment of silcrete represents an indisputable advantage for lithic production on silcrete and MSA people may have deliberately manipulated this physical transformation. Nonetheless, the question of intentionality, invention and mastering of heat treatment needs to be discussed with reference to specific technological contexts. The hypothesis that the mastering of heat treatment is at the origin of advanced technology during the MSA seems unlikely in the light of our results and requires further investigation.

The model suggested by our preliminary study needs to be corroborated by further analyses of the properties and transformation of archaeological silcrete, such as the exact determination of the temperatures used for the treated artefacts, their petrography and their silanole content. The volume of heat-treated silcrete blocks larger than $80 \mathrm{~cm}^{3}$ can also be expected to influence on the heating procedure and must be taken into account together 
with their physical and chemical properties (Work currently in progress for the MSA sequence of Diepkloof). This first study shows nonetheless that a direct comparison between heat treatment in the MSA and more recent examples of the systematic transformations of raw material (dating from the European Upper Palaeolithic) is not as straightforward as it might appear at first glance.

\section{Acknowledgements}

We thank Simon Puaud from the Muséum national d'histoire naturelle, Dpt. de Préhistoire UMR 7194, for his collaboration to the acquisition of the powder diffraction data. We are also indebted to Anne Davidson from the Laboratoire de réactivité de surface (LRS), UPMC - UMR 7197, for her collaboration to the acquisition of the IR diffuse reflection spectra. The scientific project and excavation at Diepkloof have been funded by the French Ministry of Foreign Affairs (MAE), the Aquitaine region, the Provence-Alpes-Côted'Azur region and by the Centre National de la Recherche Scientifique (CNRS). We are also thankful to the Paleontological Scientific Trust (PAST) and the National Research Foundation (NRF) of South Africa for funding. The University of Cape Town has been of great support in providing space, facilities and other logistical help. We also thank D. \& M. van Wyk and J. Pollet for permission to work on their land, as well as the Heritage Western Cape (HWC) for permits to excavate at DRS.

\section{References}

Ambrose, S.H., Lorenz, K.G., 1990. Social and ecological models for the Middle Stone Age in Southern Africa. In: Mellars, P. (Ed.), The Emergence of Modern Humans: an Archaeological Perspective. Edinburgh University Press, Edinburgh, pp. 3-33.

Backwell, L., d'Errico, F., Wadley, L., 2008. Middle Stone Age bone tools from the Howiesons Poort layers, Sibudu Cave, South Africa. Journal of Archaeological Science 35 (6), 1566-1580.

Binder, D. 1984. Systèmes de débitage laminaire par pression: exemples chasséens provençaux. In: Tixier, J., Inizan, M.L., Roche, H. (Eds.), Préhistoire de la pierre taillée, 2: économie du débitage laminaire: technologie et expérimentation: IIIe table ronde de technologie lithique. Meudin-Bellevue, octobre 1982. Cercle de Recherches et d'Etudes Préhistoriques, Paris, pp. 71-84.

Bordes, F., 1969. Traitement thermique du silex au Solutréen. Bulletin de la Société préhistorique française 66 (7), 197.

Brown, K., Marean, C., 2010. Wood fuel availability for heat treatment drives the rise and fall of silcrete as a raw material in the Middle stone Age of South Africa. Abstracts of the PaleoAnthropology Society 2010 Meetings. PaleoAnthropology, A0001-A0040.

Brown, K.S., Marean, C.W., Herries, A.I.R., Jacobs, Z., Tribolo, C., Braun, D., Roberts, D.L., Meyer, M.C., Bernatchez, J., 2009. Fire as an engineering tool of early modern humans. Science 325 (5942), 859-862.

Cartwright, C., 2013. Identifying the woody resources of Diepkloof Rock Shelter (South Africa) using scanning electron microscopy of the MSA wood charcoal assemblages. Journal of Archaeological Science 40, 3463-3474.

Charrié-Duhaut, A., Porraz, G., Cartwright, C., De Araujo, M., Conan, J., Poggenpoel, C., Texier, P.-J., 2013. First molecular identification of a hafting adhesive in the Late Howiesons Poort at Diepkloof Rock Shelter, Western Cape, South Africa. Journal of Archaeological Science 40, 3506-3518.

Crabtree, D.E., Butler, B.R., 1964. Notes on experiment in flint knapping: 1 heat treatment of silica materials. Tebiwa 7,1-6.

Domanski, M., Webb, J.A., 1992. Effect of heat treatment on siliceous rocks used in prehistoric lithic technology. Journal of Archaeological Science 19 (6), 601-614

Domanski, M., Webb, J.A., Boland, J., 1994. Mechanical properties of stone artefact materials and the effect of heat treatment. Archaeometry 36 (2), 177-208.

Eriksen, B.V., 2006. Colourful lithics - the "Chaîne opératoire" of heat treated Chert artefacts in the early Mesolithic of Southwest Germany. In: Kind, C.J. (Ed.), After the Ice Age. Settlements, Subsistence and Social Development in the Mesolithic of Central Europe, Materialhefte zur Archäologie in Baden-Württemberg. Konrad Theiss Verlag, Stuttgart, pp. 147-153.

Flenniken, J.J., Garrison, E.G., 1975. Thermally altered novaculite and stone tool manufacturing techniques. Journal of Field Archaeology 2, 125-131.

Flörke, O.W., Köhler-Herbertz, B., Langer, K., Tönges, I., 1982. Water in microcrystalline quartz of volcanic origin: agates. Contributions to Mineralogy and Petrology 80 (4), 324-333.

Fukuda, J., Nakashima, S., 2008. Water at high temperatures in a microcrystalline silica (chalcedony) by in-situ infrared specroscopy: physicochemical states and dehydration behavior. Journal of Mineralogical and Petrological Sciences 103, $112-115$.

Graetsch, H., Flörke, O.W., Miehe, G., 1985. The nature of water in chalcedony and opal-C from Brazilian agate geodes. Physics and Chemistry of Minerals 12 (5), 300-306.

Henshilwood, C., d'Errico, F., Vanhaeren, M., van Niekerk, K., Jacobs, Z., 2004. Middle Stone Age shell beads from South Africa. Science 304 (5669), 404.

Henshilwood, C., d'Errico, F., Yates, R., Jacobs, Z., Tribolo, C., 2002. Emergence of modern human behavior: Middle Stone Age engravings from South Africa. Science 295, 1278-1280.

Hester, T.R., 1972. Ethnographic evidence for the thermal alteration of siliceous stone. Tebiwa $15,63-65$.

Inizan, M.L., Tixier, J., 2001. L'émergence des arts du feu: le traitement thermique des roches siliceuses. Paléorient 26 (2), 23-36.

Jacobs, Z., Roberts, R.G., 2009. Catalysts for Stone Age innovations: what might have triggered two short-lived bursts of technological and behavioral innovation in southern Africa during the Middle Stone Age? Communicative \& Integrative Biology 2 (2), 191-193.

Kenoyer, J.M., Vidale, M., Bhan, K.K., 1991. Contemporary stone bead making in Khambhat, India: patterns of craft specialisation and organisation of production as reflected in the archaeological record. World Archaeology 23 (1), 45-63.

Klein, R., 1995. Anatomy, behavior, and modern human origins. Journal of World Prehistory 9 (2), 167-198. http://dx.doi.org/10.1007/bf02221838.

Kronenberg, A.K., 1994. Hydrogen speciation and chemical weakening of quartz. In: Heaney, P.J., Prewitt, C.T., Gibbs, G.V. (Eds.), Silica: Physical Behaviour, Geochemistry and Materials Applications. Reviews in Mineralogy, vol. 29. Mineralogical Society of America, Washington, pp. 123-176.

Le Bourhis, E., 2008. Glass Mechanics and Technology. Wiley, Weinheim.

Léa, V., 2004. Centres de production et diffusion des silex bédouliens au Chasséen. Gallia préhistoire 46, 231-250.

Léa, V., 2005. Raw, pre-heated or ready to use: discovering specialist supply systems for flint industries in mid-Neolithic (Chassey culture) communities in southern France. Antiquity 79, 1-15.

McBrearty, S., Brooks, A.S., 2000. The revolution that wasn't: a new interpretation of the origin of modern human behavior. Journal of Human Evolution 39 (5), 453-563.

Mercieca, A., Hiscock, P., 2008. Experimental insights into alternative strategies of lithic heat treatment. Journal of Archaeological Science 35 (9), 2634-2639.

Michel-Levy, A., Munier-Chalmas, C.P.E., 1892. Mémoire sur les diverses formes affectées par le réseau élémentaire du quartz. Bulletin de la société minéralogique de France 7, 159-195.

Miller, C.E., Goldberg, P., Berna, F., 2013. Geoarchaeological investigations at Diepkloof Rock Shelter, Western Cape, South Africa. Journal of Archaeological Science 40, 3432-3452.

Mourre, V., Villa, P., Henshilwood, C.S., 2010. Early use of pressure flaking on lithic artifacts at Blombos Cave, South Africa. Science 330 (6004), 659-662.

Parkington, J., Rigaud, J.-P., Poggenpoel, C., Porraz, G., Texier, P.-J., 2013. Introduction to the project and excavation of Diepkloof Rock Shelter (Western Cape, South Africa): a view on the Middle Stone Age. Journal of Archaeological Science 40, 3369-3375.

Porraz, G., Texier, P.-J., Archer, W., Piboule, M., Tribolo, C., 2013. Technological successions in the Middle Stone Age sequence of Diepkloof Rock Shelter Western Cape, South Africa. Journal of Archaeological Science 40, 3376-3400.

Purdy, B.A., Brooks, H.K., 1971. Thermal alteration of silica minerals: an archeological approach. Science 173 (3994), 322-325.

Rios, S., Salje, E.K.H., Redfern, S.A.T., 2001. Nanoquartz vs. macroquartz: a study of the a - $\beta$ phase transition. The European Physical Journal B 20, 75-83.

Roberts, D.L., 2003. Age, Genesis and Significance of South African Coastal Belt Silcretes, Memoir 95. Council for Geoscience, Pretoria.

Schindler, D.L., Hatch, J.W., Hay, C.A., Bradt, R.C., 1982. Aboriginal thermal alteration of a Central Pennsylvania jasper: analytical and behavioral implications. American Antiquity 47 (3), 526-544.

Schmidt, P., 2011. Traitement thermique des silicifications sédimentaires, un nouveau modèle des transformations cristallographiques et structurales de la calcédoine induites par la chauffe. Unpublished Doctoral thesis, Muséum national d'histoire naturelle, Paris.

Schmidt, P., Badou, A., Fröhlich, F., 2011. Detailed FT near-infrared study of the behaviour of water and hydroxyl in sedimentary length-fast chalcedony, $\mathrm{SiO}_{2}$, upon heat treatment. Spectrochimica Acta Part A: Molecular and Biomolecula Spectroscopy 81 (1), 552-559.

Schmidt, P., Bellot-Gurlet, L., Slodczyk, A., Fröhlich, F., 2012a. A hitherto unrecognised band in the Raman spectra of silica rocks: influence of hydroxylated $\mathrm{Si}-\mathrm{O}$ bonds (silanole) on the Raman moganite band in chalcedony and flint $\left(\mathrm{SiO}_{2}\right)$. Physics and Chemistry of Minerals 39 (6), 455-464. http://dx.doi.org/10.1007/ s00269-012-0499-7.

Schmidt, P., Fröhlich, F., 2011. Temperature dependent crystallographic transformations in chalcedony, $\mathrm{SiO}_{2}$, assessed in mid infrared spectroscopy. Spectrochimica Acta Part A: Molecular and Biomolecular Spectroscopy 78 (5), 1476-1481.

Schmidt, P., Léa, V., Sciau, P., Fröhlich, F. Detecting and quantifying heat treatment of flint and other silica rocks: a new non-destructive method applied to heattreated flint from the Neolithic Chassey culture, southern France. Archaeometry, in press.

Schmidt, P., Masse, S., Laurent, G., Slodczyk, A., Le Bourhis, E., Perrenoud, C. Livage, J., Fröhlich, F., 2012b. Crystallographic and structural transformations of sedimentary chalcedony in flint upon heat treatment. Journal of Archaeological Science 39 (1), 135-144. 
Scholze, H., 1960. Über die quantitative UR-spektroskopische Wasserbestimmung in Silikaten. Fortschritte der Mineralogie 38 (2), 122-123.

Sosman, R.B., 1927. The Properties of Silica. The Chemical Catalog, New York.

Summerfield, M.A., 1983. Petrography and diagenesis of silcrete from the Kalahari Basin and Cape coastal zone, Southern Africa. Journal of Sedimentary Research 53 (3), 895-909.

Texier, P.-J., Porraz, G., Parkington, J., Poggenpoel, C, Rigaud, J.-P., Poggenpoel, C. Tribolo, C., 2013. The context, form and significance of the MSA engraved ostrich eggshell collection from Diepkloof Rock Shelter, Western Cape, South Africa. Journal of Archaeological Science 40, 3412-3431.

Texier, P.-J., Porraz, G., Parkington, J., Rigaud, J.-P., Poggenpoel, C., Miller, C.E., Tribolo, C., Cartwright, C., Coudenneau, A., Klein, R., Steele, T., Verna, C., 2010. A Howiesons Poort tradition of engraving ostrich eggshell containers dated to 60000 years ago at Diepkloof Rock Shelter. South Africa Proceedings of the National Academy of Sciences 29, 1001-1015.

Tiffagom, M., 1998. Témoignages d'un traitement thermique des feuilles de laurier dans le Solutréen supérieur de la grotte du Parpalló (Gandia, Espagne). Paléo 10,147-161.
Tribolo, C., Mercier, N., Douville, E., Joron, J.-L., Reyss, J.-L., Rufer, D., Cantin, N., Lefrais, Y., Miller, C.E., Parkington, J., Porraz, G., Rigaud, J.-P., Texier, P.-J., 2013. OSL and TL dating of the Middle Stone Age sequence of Diepkloof Rock Shelter (Western Cape, South Africa): a clarification. Journal of Archaeological Science 40, 3401-3411.

Wadley, L., Hodgskiss, T., Grant, M., 2009. Implications for complex cognition from the hafting of tools with compound adhesives in the Middle Stone Age, South Africa. Proceedings of the National Academy of Sciences 106 (24), 9590-9594.

Wang, J., Li, R., Zhang, Z., Sun, W., Wang, X., Xing, Z., Xu, R., Zhang, X., 2008. Heat treatment of nanometer anatase powder and its photocatalytic activity for degradation of acid red B dye under visible light irradiation. Inorganic Materials 44 (6), 608-614. http://dx.doi.org/10.1134/ s0020168508060125.

Wopfner, H., 1978. Silcretes of northern South Australia and adjacent regions. In: Langford-Smith, T. (Ed.), Silcrete in Australia. Department of Geography, University of New England, Armidale, pp. 93-142. 